\title{
ŠAULIŠKASIS ASPEKTAS LIETUVOS \\ PARLAMENTARIZMO ISTORIJOJE: STEIGIAMOJO SEIMO ATVEJIS
}

\author{
Dokt. Mindaugas Nefas
}

Lietuvos edukologijos universiteto Istorijos fakultetas

Lithuanian University of Educational Sciences, Faculty of History

T. Ševčenkos g. 31, LT-03111 Vilnius

El.paštasmindaugas.nefas@leu.lt

\section{Santrauka}

Straipsnyje analizuojamas Lietuvos šauliu sajungos veiksnys Steigiamojo Seimo darbe. Remiantis Steigiamojo Seimo narių biografiniu žodynu, Šauliu sajungos Centro valdybos posėdžiu ir Steigiamojo Seimo protokolais, istoriografine medžiaga, nagrinejama 1920-1922 metais Steigiamajame Seime dirbusiu šios organizacijos nariu veikla ịtvirtinant įstatymiška Lietuvos šauliu sajungos pagrindą. Ši sukarinta organizacija veikla pradejo vykstant kovoms dèl Lietuvos Nepriklausomybès ir tokiu būdu užsitarnavo Lietuvos valdžios pasitikejjima. Pagal veiklos principus tai nebuvo analogu neturinti organizacija, tačiau jos veikla reglamentavo istatymai - tai Šauliu sajunga teisiniu požiūriu padarè išskirtine organizacija. Šauliu palaikymas politiniu lygmeniu nebuvo vienodas. Steigiamasis Seimas reiške pasitikẹjimą šia organizacija (pavyzdys - $1921 \mathrm{~m}$. priimtas Lietuvos šauliu sajungos įstatymas), o Krašto apsaugos ministerija siekè visapusiškai kontroliuoti šaulius, panaikindama savarankiško valdymo galimybes. 1921 m. priimtas pirmasis Lietuvos šauliu sajungos įstatymas buvo svarbus ịrodymas, kad Lietuvos valdžia vertina organizacijos nariu veikla, be to, jis itvirtino tik daline organizacijos priklausomybę nuo Krašto apsaugos ministerijos. 
Reikšminiai žodžiai: Lietuvos šaulių sąunga; Steigiamasis Seimas; ìstatymas; Krašto apsaugos ministerija; parlamentarizmas; šauliškumas.

\section{Ivadas}

1919 m. vasarą ịkurta Lietuvos šaulių sąjunga (toliau - LŠS) pagal veiklos pobūdị nebuvo unikali, analogų Vidurio ir Rytų Europoje neturinti organizacija. Dar XIX a. viduryje Europoje pradejo formuotis organizacijos, vèliau igijusios sukarintos veiklos pobūdị. Šis procesas ypač paspartëjo baigiantis Pirmajam pasauliniam karui. Istoriko Viljamo Rozenbergo teigimu, svarbiausia paramilitarinių organizacijų kūrimosi priežastis buvo chaotiška padètis po Rusijos revoliucijos ${ }^{1}$. Žinoma, situaciją lèmė vidaus padètis Vidurio ir Rytų Europos teritorijose, dèl Pirmojo pasaulinio karo susiklosčiusių aplinkybių šiame regione pradètos kelti nepriklausomos valstybės idejos. Antrasis veiksnys yra susijęs su sukarintos organizacijos - Šaulių sąungos - ịkūrimu Lietuvoje. Sukarintos organizacijos, kurioms priklausè civiliai asmenys, buvo svarbios įtvirtinant Nepriklausomybę ne tik Lietuvoje, bet ir kitose regiono valstybèse: Latvijoje, Estijoje ir Suomijoje.

Iki SSRS ekspansijos Antrojo pasaulinio karo metais (1939-1940) sukarintos organizacijos tapo ne tik platforma, kuriai priklausantys civiliai galèjo išmokti valdyti ginklą, bet ir svarbiomis kultūrinėmis organizacijomis. Lietuvos šaulių sąjungos padetis 1919-1940 metais buvo išskirtinè, nes Lietuvoje, priešingai nei kitose valstybėse, iki 1935 m. LŠS pertvarkos buvo išlaikytas stiprus ir aiškus visuomeninis organizacijos pagrindas. Tai reiškè, kad organizacijai asmenys priklausydavo savo noru, buvo renkamos ịvairių lygių šaulių padalinių vadovybès (pvz.: Centro valdyba (toliau - CV) ir jos pirmininkas, rinktinès valdybos ir jų pirmininkai, būrių valdybos ir jų pirmininkai). Nepaisant to, LŠS kartu buvo tvirtai susijusi su Krašto apsaugos ministerija (toliau -

1 Gerwarth, R., Horne, J. Karas taikos metu: paramilitarizmas po Pirmojo pasaulinio karo 1917-1923 m. Vilnius, 2013, p. 15. 
KAM) ir šioje situacijoje buvo užkoduotas konfliktas - kieno viršenybė bus aukštesnè: krašto apsaugos ministro ar šaulių rinkto CV pirmininko. Egzistuojant tokiai situacijai, susiformavo dvilypė ir išskirtinè organizacijos veiklos sistema.

Ieškant LŠS unikalumo ir esminio skirtumo nuo kitų sukarintų organizacijų regione, verta pažiūrèti ị teisinę bazę. Tokio tipo organizacija buvo itin reikalinga Lietuvos kariuomenei kaip pagalbininkè, todèl LŠS veikla buvo ịteisinta dar 1919 m. rugpjūčio 15 d., krašto apsaugos ministrui patvirtinus pirmuosius organizacijos įstatus ${ }^{2}$. Iki tol šauliai veikè po Lietuvos sporto sąjungos priedanga. Vèliau LŠS veiklą reglamentavo 1921, 1924 ir 1935 m. priimti organizacijos įstatymai ir krašto apsaugos ministro, o nuo $1935 \mathrm{~m}$. - kariuomenès vado, tvirtinami statutai. Kitos organizacijos atskirų ịstatymų neturejo, nes buvo iki galo integruotos $\mathfrak{i}$ valstybinę administravimo ir krašto gynybos sistemas. Pirmasis organizacijos įstatymas buvo priimtas Steigiamojo Seimo, kuris per kadenciją prièmè 268 teisès aktus ${ }^{3}$.

Straipsnyje bus analizuojamas šauliškasis veiksnys Steigiamajame Seime 1920-1922 metais. Ką galime vadinti šauliškuoju veiksniu? Steigiamojo Seimo priimtas LŠS įstatymas yra svarbus teisinis įvykis, nes tuo metu organizacija skaičiavo tik trečiuosius veiklos metus. Politinè itampa tarp organizacijos vadovybès ir KAM buvo didelè, nes pastaroji siekè visapusiškai kontroliuoti ginkluotąsias pajègas - tokia tuomet buvo ir LŠS. Paprasčiausias kelias, kuriuo ženge ir kaimyninės šalys tokio tipo organizacijas visiškai integruoti ị valstybinę sistemą. Tačiau Vlado Putvinskio idejja buvo kardinaliai priešinga, jis siekè, kad organizacija taptų kariuomenès pagalbininke, būtų šalia kariuomenės, būtų tautos kariuomene, o ne taptų viena iš jos dalių ar pakeistų ją ${ }^{4}$. Taigi

192006 27-28. LŠS atstovų suvažiavimo protokolas. LCVA. F. 561, ap. 2, b. 47, lap. 59.

3 Lietuvos Steigiamojo Seimo (1920-1922 metu) nariu biografinis žodynas. Sudarytojai A. Ragauskas, M. Tamošaitis. Vilnius, 2006, p. 484.

4 Ten pat, p. 25. 
svarbu ištirti, kodèl Steigiamasis Seimas, priimdamas LŠS įstatymą, pasisake už organizacijos visuomeniškumo išlaikymą, kartu palikdamas KAM teisę kontroliuoti šaulius. Be to, iki šiol istoriografijoje nebandyta apčiuopti šaulių lobistinės veiklos parlamente. Organizacijai priklausė nemažai žymių to meto politikos veikèjų, kurių dalis $1920 \mathrm{~m}$. ir vèliau tapo Steigiamojo Seimo nariais. Tad išanalizavus jų pasisakymus ir pozicijas svarstant pirmąji LŠS ịstatymą, svarbu ištirti, ar jie turejjo ịtakos Steigiamajame Seime priimant sprendimus dèl organizacijos ateities. Visa tai sudaro šauliškojo veiksnio visumą.

Tyrimo aktualumą rodo pastaraisiais metais išaugęs susidomėjimas LŠS. Tai lèmè sudètinga geopolitinè situacija Rytų Europoje, Rusijos ir Ukrainos konfliktas. Nuo $2014 \mathrm{~m}$. prie organizacijos prisijungè nemažai gana ryškių Lietuvos politikos, verslo ir kultūros atstovų. Lietuvos Respublikos Seime 2014-2015 metais LŠS įstatymo pataisos buvo svarstomos net kelis kartus. Tai rodo, kad ne tik visuomenè, bet ir šalies parlamentas susidomėjo šios sukarintos visuomeninès organizacijos veikla ${ }^{5}$. Faktiškai iki krizès Ukrainoje LŠS buvo laikoma pagyvenusių vyrų ir jaunimo (iki 18 metų) organizacija. Pastaruoju laikotarpiu toks požiūris ima keistis. Kilus susidomejjimui organizacija, iškilo ir poreikis domètis šaulių istorija. Tad istorinis LŠS tyrimas orientuojasi ir $\mathfrak{i}$ dabartinę LŠS teisinès bazès situaciją.

Darbo tikslas - nustatyti, kokią ịtaką Lietuvos šaulių sąjungos teisinès bazès kūrimui turèjo šiai organizacijai priklausę Steigiamojo Seimo nariai. Išsikelto tikslo bus siekiama nustatant Steigiamajame Seime dirbusių šaulių skaičių ir analizuojant jų indèlị parlamente priimant organizacijos veiklą reglamentuojančius teisès aktus.

2014 m. LŠS nariais tapo tuomečiai Lietuvos Respublikos Seimo nariai: Eligijus Masiulis, Gintaras Steponavičius, Remigijus Šimašius, Petras Auštrevičius (Lietuvos Respublikos liberalu sajunga), Juras Požela, Juozas Olekas (Lietuvos socialdemokratų partija). Taip pat organizaciją papildè ir daugiau politikų, pavyzdžiui, Europos Parlamento narys Gabrielius Landsbergis. 
LŠS Lietuvos parlamentarizmo istorijoje iki šiol yra skirtas tik epizodinis vaidmuo. Visi tyrimai dėmesį koncentruoja ị Šaulių sąjungos raidą, pernelyg neakcentuodami šios organizacijos vadovybės santykių su Lietuvos valdžia. Apsiribojama tik santykių tarp LŠS ir KAM aptarimu. Šauliškajji veiksnị Lietuvos parlamentų istorijoje išsamiau yra nagrinejęs tik Gintaras Žilinskas ${ }^{6}$. Jis analizavo pirmuosius du LŠS įstatymus (1921 ir 1924 m.), nagrinèjo jų prièmimo aplinkybes, išryškino kai kurių Lietuvos politikų ir politinių jègų požiūrị i ̌ią sukarintą organizaciją. Tačiau autorius netyrè, kokią ịtaką šių ịstatymų svarstymui turejjo parlamentarai šauliai.

Teisinius LŠS veiklos pagrindus ir šaulius Lietuvos parlamentuose yra nagrinejęs Audrius Skaistys ${ }^{7}$. Savo tyrime pagrindinị dèmesị jis skyrè šaulių ižado arba priesaikos reikšmei, kaitai ir pan. Taip pat tyrime bandoma nagrinėti, kiek procentiškai šaulių buvo ne tik Steigiamajame, bet ir I-IV Seimuose. Autorius pateikia neišsamius ir klaidingus duomenis. Jie yra tikslinami šiame straipsnyje. Taip pat vertètu paminèti Aušros Jurevičiūtès straipsnị, kuriame ji analizavo Steigiamojo Seimo sudaryto Vyriausiojo Lietuvos gynimo komiteto veiklą ${ }^{8}$.

Be galo svarbiu šaltiniu nagrinėjant šią temą buvo Steigiamojo Seimo narių biografinis žodynas ${ }^{9}$. Remiantis juo pavyko nustatyti didžiąją dalị Steigiamojo Seimo narių, priklausiusių LŠS. Žinoma, apie narystę šioje organizacijoje yra pateikiami tik minimalūs duomenys, tad juos reikètu tikslinti ir koreguoti, taip pat ittraukti naujos informacijos.

${ }^{6}$ Žilinskas, G. Lietuvos Respublikos Seimai ir Šaulių Sajunga. Šauliškumas, tautiškumas ir Lietuvos Nepriklausomybė. Sudarytojas A. Liekis. Vilnius, 1993, p. 37-50.

7 Skaistys, A. Šaulio priesaikos misija ir jos ịgyvendinimas. Socialiniu mokslu studijos. 2011, Nr. 3(2), p. 687-708.

8 Jurevičiūtè, A. Vyriausiasis Lietuvos gynimo komitetas 1920- 922 metais. Steigiamajam Seimui - 90. Sudarytojai S. Kaubrys, A. Vyšniauskas. Vilnius, 2011, p. 133-158.

9 Lietuvos Steigiamojo Seimo (1920-1922 metu) narių biografinis žodynas. Sudarytojai A. Ragauskas, M. Tamošaitis. Vilnius, 2006. 
Šauliškajji veiksnị Steigiamajame Seime atskleisti leidžia LŠS $\mathrm{CV}$ protokolai, saugomi Lietuvos centriniame valstybès archyve $(\text { LCVA })^{10}$. Steigiamojo Seimo posèdžiuose buvo nemažai diskutuojama dèl svarstomo organizacijos ịstatymo, veiklos krypčių. Juose aktyviai dalyvavo šauliai Steigiamojo Seimo nariai. Taip pat šiame tyrime buvo panaudota oficiali LSSS vadovybès informacija, skelbta šaulių laikraštyje „Trimitas“, ir Steigiamojo Seimo stenogramos ${ }^{11}$.

\section{1. Šauliai Steigiamojo Seimo nariai}

Kovų dèl Lietuvos Nepriklausomybės metu sukurta Lietuvos šaulių sąjunga pakankamai greitai išplètè ne tik veiklos teritoriją, bet ir narių skaičių $1920 \mathrm{~m}$. birželio $1 \mathrm{~d}$. buvo išduota 11780 šaulio pažymèjimų. Tačiau, kaip pažymi V. Jokubauskas, tai jokiu būdu nereiškè, kad tuo metu tiek narių ir buvo LŠS ${ }^{12}$. Vis dèlto didžiąją dalį to meto LŠS narių vienijo kariniai veiksmai, o ne aiški ir nuosekli ideologija. Faktiškai didžioji dalis organizacijos narių save šauliais laike tiek, kiek tai buvo susiję su kariniais veiksmais. Ryšiai su vadovybe buvo menki, o ir joje trūko aiškumo. 1920 m. vasario 15 d. Kaune vykusiame pirmajame LŠS skyrių atstovų suvažiavime dalyvavo tik 13 skyrių atstovu ir Centro valdybos nariai, tad suvažiavimas nebuvo teisètas ir pripažintas tik patariamuoju ${ }^{13}$. Nepaisant to, jame aktyviai dalyvavo (pasisake ir diskutavo) ir būsimi Steigiamojo Seimo nariai Kipras Bielinis ir Kazimieras Ralys bei vèliau žymiu valstiečių liaudininkų veikẻju tapęs Vincas Kvieska.

${ }^{10}$ LCVA. F. 561, ap. 2.

11 Steigiamojo Seimo darbai. Kaunas, 1920-1922.

12 Jokubauskas, V. Lietuvos šauliai tarpukariu: lietuviai, katalikai, visuomenès elitas. Paramilitarizmas Rytu Baltijos regione 1918-1940: atvejo studijos ir lyginimai. Klaipėda, 2014, p. 78. (Acta historica universitatis Klaipedensis; t. 28).

13192002 15. LŠS skyrių atstovų suvažiavimo protokolas. LCVA. F. 561, ap. 2, b. 46, lap. 22-23. 
Taigi sunkiau identifikuoti asmenis, kurie tikrai buvo LŠS nariais, ir dar sudètingiau nustatyti, kurie iš jų save tapatino su šauliais. Remiantis "Lietuvos Steigiamojo Seimo narių biografiniu žodynu“, Steigiamajame Seime per visą kadenciją 1920-1922 m. iš viso dirbo 22 šauliai $^{14}$. Tačiau ne prie visų šiame parlamente dirbusių asmenų yra nurodyti duomenys, rodantys jų narystę LŠS. Tarp tokių reikètų itraukti organizacijos Centro valdyboje dirbusius Kiprą Bielinị ${ }^{15}$ ir Mykolą Krupavičių, LŠS garbès teismui priklausiusị Prezidentą Kazị Grinių $^{16}$ ir Steigiamojo Seimo narị Juozą Pronskų (priklausė LŠS Literatų komisijai ir dirbo šaulių laikraštyje „Trimitas“). Patikslinus žodyne pateikiamus duomenis galima teigti, jog 1920-1922 metais Steigiamajame Seime dirbo ne mažiau kaip 26 Šaulių sąjungai priklausę asmenys. Ši skaičių gali pakoreguoti išsamesnẻ kiekvieno parlamentaro veiklos ir gyvenimo analizè. Pavyzdžiui, keletas Steigiamojo Seimo narių kovų dèl Lietuvos Nepriklausomybès metais kovojo partizanų junginiuose ${ }^{17}$, kurių nemaža dalis vèliau buvo integruota i LŠS sudètį. Tad šis skaičius ateityje gali būti patikslintas. Iš viso 1920-1922 m. Steigiamajame Seime dirbo 150 asmenų (38 asmenys pakeite atsisakiusius mandato $)^{18}$, taigi šauliai sudarè 17,3 proc. visų Steigiamojo Seimo narių. Be jau minètų politinių asmenybių, verta išskirti šaulius karininkus Antaną Matulaitị ir Petrą Rusecką, vidaus reikalų ministrą Eliziejų Draugelị, gydytoją Joną Staugaitị.

${ }^{14}$ Lietuvos Steigiamojo Seimo (1920-1922 metu) narių biografinis žodynas. Sudarytojai A. Ragauskas, M. Tamošaitis. Vilnius, 2006, p. 62-449.

15192006 27-28. LŠS atstovų suvažiavimo protokolas. LCVA. F. 561, ap. 2, b. 47, lap. 29.

16 1923. LŠS Garbès teismo posėdžio protokolas, Nr. 1. LCVA. F. 561, ap. 2, b. 338, lap. 1.

17 Pvz. Stasys Balčas. Lietuvos Steigiamojo Seimo (1920-1922 metu) narių biografinis žodynas. Sudarytojai A. Ragauskas, M. Tamošaitis. Vilnius, 2006, p. 75-77.

18 Blažytė- Baužienè, D. Pakeitę pasitraukusiuosius: 38 Steigiamojo Seimo narių kolektyvinès biografijos kontūrai. Steigiamajam Seimui-90. Sudarytojai S. Kaubrys, A. Vyšniauskas. Vilnius, 2011, p. 71. 
1 lentelè. Šauliai, dirbę Steigiamajame Seime 1920-1922 m.

\begin{tabular}{|l|l|l|}
\hline$N \boldsymbol{r}$. & Vardas, pavarde் & Politinis blokas \\
\hline 1. & Tadas Aleliūnas & Krikščionių demokratų blokas \\
\hline 2. & Kazimieras Ambrozaitis & Krikščionių demokratų blokas \\
\hline 3. & Vytautas Bičiūnas & Krikščionių demokratų blokas \\
\hline 4. & Kazys Bieliūnas & Valstiečių liaudininkų blokas \\
\hline 5. & Jonas Bliudžius & Valstiečių liaudininkų blokas \\
\hline 6. & Eliziejus Draugelis & Krikščionių demokratų blokas \\
\hline 7. & Petras Jočys & Krikščionių demokratų blokas \\
\hline 8. & Mykolas Krupavičius & Krikščionių demokratu blokas \\
\hline 9. & Juozas Liekis & Valstiečių liaudininkų blokas \\
\hline 10. & Morta Lukošytė & Krikščionių demokratų blokas \\
\hline 11. & Antanas Matulaitis & Krikščionių demokratų blokas \\
\hline 12. & Antanas Milčius & Krikščionių demokratų blokas \\
\hline 13. & Vytautas Račkauskas & Valstiečių liaudininkų blokas \\
\hline 14. & Pranas Radzevičius & Valstiečių liaudininkų blokas \\
\hline 15. & Kazimieras Ralys & Valstiečių liaudininkų blokas \\
\hline 16. & Mykolas Rožanskas & Krikščionių demokratų blokas \\
\hline 17. & Petras Ruseckas & Valstiečių liaudininkų blokas \\
\hline 18. & Mykolas Sleževičius & Valstiečių liaudininkų blokas \\
\hline 19. & Jonas Staugaitis & Valstiečių liaudininkų blokas \\
\hline 20. & Jonas Steponavičius & Krikščionių demokratų blokas \\
\hline 21. & Klemensas Vaitekūnas & Krikščionių demokratų blokas \\
\hline 22. & Balys Žygelis & Valstiečių liaudininkų blokas \\
\hline 23. & Vincas Žindžius & Valstiečių liaudininkų blokas \\
\hline 24. & Kipras Bielinis & Lietuvos socialdemokratų partija \\
\hline 25. & Kazys Grinius & Valstiečių liaudininkų blokas \\
\hline 26. & Juozas Pronskus & Valstiečių liaudininkų blokas \\
\hline
\end{tabular}

Nors istoriografijoje LŠS narių politinei priklausomybei atskirų tyrimų nèra skirta, dažniausiai šios organizacijos nariai laikomi dešiniųjų politinių jègų talkininkais. Tai lemė keletas veiksnių. Pirma, visi LŠS įstatymai buvo priimti valdžioje esant dešiniesiems (krikščionims demokratams arba tautininkams), o dalies kairiųjų požiū- 
ris buvo neigiamas. G. Žilinsko teigimu, Steigiamajame Seime dirbusiems socialdemokratams LŠS „buvo nepriimtina, nereikalinga organizacija" ${ }^{19}$. Antra, po $1926 \mathrm{~m}$. valstybès perversmo šauliai tapo svarbia A. Smetonos valdymo sistemos atrama, kuria "Tautos vadas“ aktyviai naudojosi. Būtina atkreipti dèmesị, kad A. Smetona dar iki 1926 m. perversmo buvo pakankamai aktyvus LŠS narys, priklausė $\mathrm{CV}$ ir netgi buvo vienas iš kandidatų tapti CV pirmininku. T. Balkelis teigia, jog po perversmo šauliai „veikè kaip jo [A. Smetonos - M. N. pastaba] politinè policija bei vidaus saugumo instrumentas ${ }^{\text {"20 }}$. Toks palyginimas yra pernelyg radikalus, bet jis gerai atspindi istoriografijoje tebevyraujantị požiūrị i LŠS. Trečia, iki XX a. 3-iojo dešimtmečio pabaigos nebuvo vedama nuosekli LŠS narių statistika, nebuvo renkami duomenys apie jų priklausymą kitoms organizacijoms ir pan.

Gilinantis ị LŠS narių politinès priklausomybès sritị verta išanalizuoti Steigiamojo Seimo narių šaulių politinę priklausomybę. Faktiškai visi šauliai priklausė dviem pagrindiniams politiniams blokams: krikščionių demokratų (12 šaulių) ir valstiečių liaudininkų (13 šaulių). Tik vienas Kipras Bielinis priklausė Lietuvos socialdemokratų partijai. Šaulių nebuvo tarp likusių politinių jègų, buvusių Steigiamajame Seime. Dėsninga, kad tarp šaulių Steigiamojo Seimo narių nebuvo tautinių grupių - žydų, lenkų ir vokiečių, atstovų. Kitataučių procentas LŠS gretose buvo itin nedidelis, šiek tiek ryškesnę grupę sudarè žydai ${ }^{21}$.

19 Žilinskas, G. Lietuvos Respublikos Seimai ir Šaulių Sajunga. Šauliškumas, tautiškumas ir Lietuvos Nepriklausomybè. Sudarytojas A. Liekis. Vilnius, 1993, p. 38 .

${ }^{20}$ Balkelis, T. Piliečiai kareiviai: paramilitariniai judejjimai Baltijos šalyse po pirmojo pasaulinio karo. Karas taikos metu: paramilitarizmas po Pirmojo pasaulinio karo 1917-1923 m. Vilnius, 2013, p. 167.

${ }^{21}$ Jokubauskas, V. „Mažuju kariuomeniu“ galia ir paramilitarizmas: tarpukario Lietuvos atvejis. Klaipeda, 2014, p. 363. 


\section{1 grafikas. Šaulių Steigiamojo Seimo narių pasiskirstymas pagal politinius blokus}

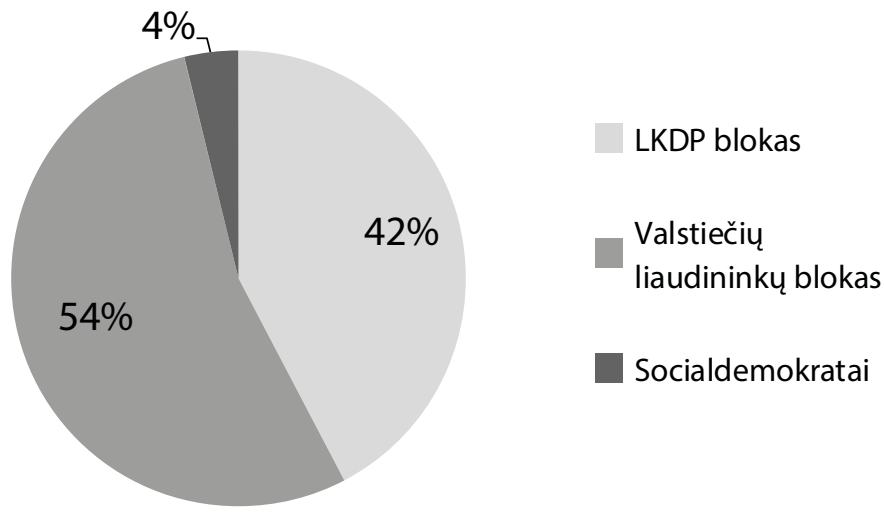

Tarp visų šaulių Steigiamojo Seimo narių didesnę dalį sudare valstiečių liaudininkų bloko atstovai. Vos vienu mandatu mažiau turèjo Lietuvos krikščionių demokratų blokas. Tarp abiejų politinių jeggu buvo ir itin ryškių politinių asmenybių, kaip antai krikščionių demokratų bloke: $\mathrm{M}$. Krupavičius, E. Draugelis, o valstiečiu liaudininkų bloke: M. Sleževičius, K. Grinius. Kriǩšionių demokratų blokas Steigiamajame Seime iš viso turëjo 59 vietas, šauliai tarp jų sudarè 20,3 proc. o tarp 29 valstiečių liaudininkų parlamentarų šauliai sudare beveik pusę $-44,8$ proc. Mažiausią dalį šauliai sudare tarp Lietuvos socialdemokratų partijos atstovų - vos 7,1 proc.

Kaip matyti iš pateiktų duomenų, nors pagal mandatus ryškaus skirtumo tarp pagrindinių politinių jègų Steigiamajame Seime nėra, tačiau procentiškai dvigubai daugiau šaulių tarp visų bloko narių buvo valstiečiu liaudininkų bloke. Kaip minèta, nors socialdemokratai priešiškai žiūrèjo i̇ šią organizaciją, jos gretose veike aktyvus šaulys K. Bielinis.

Tokia situacija susiformavo, nes 1919-1923 / 1924 m. LŠS rèmėsi „kovine“ ideologija, jos ašis buvo Lietuvos Nepriklausomybès gynyba 
su ginklu rankose. Todèl po šios organizacijos „stogu“ susibūrè ịvairių politinių pažiūrų asmenys, kuriems svarbiausias tikslas buvo apginti Lietuvos Nepriklausomybę. Vykstant kariniams veiksmams nebuvo nei laiko, nei organizacinių pajėgumų kurti nuoseklesnę ideologiją, šio darbo imtasi tik nurimus kovoms dèl Nepriklausomybès. 1922 m. pabaigoje Vladas Putvinskis ėmèsi aktyviai darbuotis kuriant organizaciją, nes pasitraukè iš LŠS vadovybès ${ }^{22}$. Tik susiformavus pagrindinėms LŠS ideologinèms nuostatoms ir pasikeitus politinei padéčiai Lietuvoje, LŠS gretose 4-ajame dešimtmetyje sustiprejo dešiniosios politinès jègos. Taigi, bent jau Steigiamojo Seimo veiklos metais (1920-1922) Lietuvos šaulių sąungoje nebuvo jaučiama politinio angažuotumo, nes jos nariai buvo įvairių politinių partijų atstovai.

\section{Kodèl reikèjo Lietuvos šalių sąjungos įstatymo?}

Nagrinëjant šauliškąji veiksnị Steigiamajame Seime, verta pažvelgti i esmines LŠS ideologines nuostatas, kurios aiškiau buvo įvardytos jau véliau. Vienas iš svarbiausių vaidmenų tenka V. Putvinskiui, kuris buvo įsitikinęs demokratas. Jis pabrèžè demokratinès valstybės reikšmę, tačiau tokio tipo valstybès netapatino vien tik su parlamento funkcionavimu. Anot jo, „demokratinė valstybė yra tik ta, kurioje demokratijos principai vadovauja visuose žmonių ir jų organizacijų tarpusaviuose santykiuose. Gali atsitikti, kad valstybès viduje gyvenimas eina demokratiškesne vaga, negu jos valdžios sistema"23. LŠS valdyme dar iki susirenkant Steigiamajam Seimui buvo siekiama ittvirtinti esminius demokratijos principus, ryškiausias to pavyzdys - šaulių padalinių atstovų suvažiavimo organizavimas. Sąungos lyderiai nesièmė vienašališkos atsakomybès spręsti Šaulių sąjungos gyvavimo ateities, nepasitarę ir nepadiskutavę su likusiais šauliais.

22 Putvinskis-Pūtvis, V. Gyvenimas ir parinktieji raštai. T. 1. Vyr. red. A. MarcinkevičiusMantautas. Čikaga, 1973, p. 228.

${ }^{23}$ Putvinskis- Pūtvis, V. Gyvenimas ir parinktieji raštai. T. 2. Vyr. red. A. MarcinkevičiusMantautas. Čikaga, 1973, p. 85. 
I Steigiamąji Seimą LŠS vadovybė žiūrèjo viltingai, tikẻdamasi, kad parlamentas padès išspręsti konfliktą dèl organizacijos ateities su KAM, kuri siekè visapusiškai kontroliuoti šią organizaciją, o pasibaigus kariniams veiksmams, paleisti arba padaryti sporto organizacija. Dar vykstant kovoms dèl Lietuvos Nepriklausomybès, tarp šaulių ir kariškių kildavo nemažai nesutarimų. $1919 \mathrm{~m}$. pabaigoje LŠS CV aktyviai kèlè klausimą, ką reikès daryti, jei valdžia nuspręs uždrausti šaulių veiklą. Tokie nuogąstavimai iškilo dèl dviejų priežasčių. Pirma, sklandẻ gandai, kuriuos skleidè eiliniai šauliai, nepatenkinti dèl veiklos suvaržymų. Antra, KAM ir kariuomenès siekis kuo griežčiau kontroliuoti Lietuvoje ịsisteigusius ginkluotų civilių būrius. Bene aktyviausiai kariškių siekiui kontroliuoti LŠS priešinosi CV valdybos narys, būsimasis Steigiamojo Seimo narys K. Ralys ${ }^{24}$. Rinkimų ị Steigiamajji Seimą laikotarpiu CV posèdžių metu neskambèjo agitacinès kalbos, bet buvo ruošiamasi teikti savo pasiūlymus dèl teisinès bazès.

LŠS siekė gauti valdžios pritarimą savo veiklai, nes darbo sąlygos buvo itin sudètingos. Tačiau situaciją sunkino skirtingas LŠS vadovybès požiūris i organizacijos ateities veiklą. Nemaža dalis šaulių LŠS ateityje ịsivaizdavo kaip pusiau karinę-sportinę organizaciją. R. Skipičio žodžiais tariant, „Šauliai turi būti daugiau sporto sąunga"25. Šiuo atveju buvo labiau siekiama išryškinti „,sokoliškajji pradą“. Kiti šauliai siekè išlaikyti specifiką palikti sukarintą organizaciją, kurią sudarytų civiliai, turintys ginklus ir mokantys jais naudotis.

Steigiamojo Seimo atidarymui LŠS vadovybè ruošèsi ir iš praktinės pusès. Dar 1920 m. pradžioje buvo pradèti formuoti specialūs šaulių daliniai, kurie buvo numatyti Steigiamojo Seimo apsaugai ${ }^{26}$. Steigiamojo Seimo darbo pradžią šauliai pasitiko džiaugsmingai, teigdami: „Seimo reikšmė

${ }^{24} 191911$ 30. LŠS CV posèdžio protokolas, Nr. 3. LCVA. F. 561, ap. 2, b. 4296, lap. 12-15.

${ }^{25} 192002$ 8. LŠS CV posèdžio protokolas, Nr. 26. LCVA. F. 561, ap. 2, b. 4296, lap. 32-33.

${ }^{26} 192002$ 26. LŠS CV posėdžio protokolas, Nr. 28. LCVA. F. 561, ap. 2, b. 4296, lap. 36. 
yra tame, kad jis sudarys tokią tvarką, kad mums bus lengva darbuotis savo ir Tëvynès labui. <...> Seimo nariai neis patys su šautuvu kautis su priešininku, bet jie padès mums sudaryti tokią Tẻvynès apsaugą, kuri kuo pigiau mums kaštuotų “27. Kaip minèta, buvo tikimasi, kad parlamente bus priimtas Šaulių sąungai palankus įstatymas. Juo labiau kad parlamente dirbo ne vienas šaulys, tarp kurių išsiskyrė K. Ralys. Steigiamajam Seimui pradejjus darbą, LŠS CV delegavo V. Putvinskị ì parlamente sudarytą Krašto apsaugos komisiją. Buvo nutarta, jog LŠS, dalyvaudama šios komisijos darbe, sieks iškelti klausimą dèl visuotinio žmonių apginklavimo ${ }^{28}$. Taip buvo išreikštas pasitikejjimas dar visai neseniai veikiančia sukarinta organizacija, o iš kitos pusès - LŠS siekis bendradarbiauti su aukščiausiu valdymo organu.

LŠS stengèsi išnaudoti Steigiamojo Seimo veiksnị kryptingai bei nuosekliai veikdama ne tik per savo narius, bet ir oficialiai kreipdamasi i Steigiamajj Seimą. $1920 \mathrm{~m}$. birželio mèn. pabaigoje vykusiame antrajame LŠS atstovų suvažiavime (šị kartą jame dalyvavo 39 padalinių atstovai ir $8 \mathrm{CV}$ nariai, tad jis buvo teisètas) sveikinant Steigiamąji Seimą, dar kartą išreikšta viltis, kad „Steigiamasis Seimas pilnai legalizuos mūsų Sajungą, teiks jai paramos ir sudarys jai tokias gyvenimo sąlygas, kad ji galètų visoj Lietuvoj plačiai išplèsti savo darbuotę ${ }^{\text {"29. }}$.

Tuo metu šaulių santykiams su kariuomene ypač kenkẻ savavališki šaulių veiksmai (kariuomenès požiūriu) atliekant žvalgybą, kovojant su priešais ir dèl to kylantys konfliktai. Kariuomenès atstovai dažnai konfiskuodavo šaulių ginklus, drausdavo vykdyti karines operacijas. Šauliams buvo būtinas užtarimas aukščiausiame lygmenyje, nes jie veikė pagal 1919 m. krašto apsaugos ministro patvirtintus ịstatus, todèl nuolatos buvo jaučiamas siekis riboti veiklą. Nepaisant to, Steigiamasis Seimas neskubè-

27 Šaulys, L. Steigiamasis. Trimitas. 1920, Nr. 1, p. 34.

28192005 28. LŠS CV posėdžio protokolas, Nr. 31. LCVA. F. 561, ap. 2, b. 4296, lap. 39.

29192006 27-28. LŠS atstovų suvažiavimo protokolas. LCVA. F. 561, ap. 2, b. 47, lap. 55-56. 
jo priimti LŠS veiklą ịteisinančio ịstatymo. Juolab kad šis klausimas tikrai nepriklausė svarbiausiųjų grupei. K. Bielinio teigimu, sudètingiems santykiams tarp LŠS vadovybès ir KAM įtakos galejjo turèti faktas, jog CV iki antrojo šaulių suvažiavimo buvo neteisèta, be to, šaulys Steigiamojo Seimo narys kritikavo organizaciją, kad ši nedaug dèmesio skiria organizaciniams dalykams ${ }^{30}$. Kritika buvo teisinga, tačiau menkai pagrịsta, nes 1919-1920 metais Šaulių sąjungos vadovybei didžiąą laiko dalį užimdavo fronto ir buitinių reikalų sprendimas.

Šaulių santykiai su Lietuvos valdžia ir karine vadovybe èmè keistis 1920 m. rugsėjo 22 d. prasidejjus plačiam Lenkijos puolimui. Būtent tuomet Steigiamasis Seimas pademonstravo pasitikejimą dar jauna sukarinta organizacija. Rugsèjo $27 \mathrm{~d}$. Steigiamojo Seimo prezidiumas kreipèsi $\mathfrak{i}$ Ministrą Pirmininką Kazi Grinių reikalaudamas: patvirtinti LŠS įstatus, pateikti svarstyti organizacijos ịstatymo projektą, ịsakyti kariuomenės daliniams netrukdyti veikti šaulių daliniams, skirti Šaulių sąungai karinius instruktorius ir suteikti finansavimą ${ }^{31}$. Tokia parlamento pozicija stiprino Šaulių sajungą, tačiau kartu ịpareigojo aktyviau prisidèti prie Lietuvos gynybos nuo lenkų. Be to, LŠS viršininkas V. Putvinskis rugsẻjo mèn. pabaigoje tapo ịsteigto Vyriausiojo Lietuvos gynimo komiteto nariu. Aušros Jurevičiūtès teigimu, šis pasirinkimas „rodè didžiulị valstybès pasitikẻjimą jauna organizacija“32. Lenkijai atnaujinus puolimą, Lietuvai reikejjo jègos, kuri gebètų îkvèpti visuomenę priešintis. Todèl iškilo visuomeninès organizacijos, kuri tuo metu ieškojo savasties, veiksnys. Šiame komitete šauliams teko svarbus vaidmuo: iš 10 jo narių 4 buvo LŠS nariai, tarp jų ir pirmininkas M. Sleževičius bei jo pavaduotojas M. Krupavičius. Taip pat

${ }_{30} 192006$ 27-28. LŠS atstovų suvažiavimo protokolas. LCVA. F. 561, ap. 2, b. 47, lap. 61.

${ }^{31}$ Lietuvos šauliu sajunga valstybès ir visuomenès tarnyboje, 1919-2004. Kaunas, 2005, p. 47.

32 Jurevičiūte, A. Vyriausiasis Lietuvos gynimo komitetas 1920-1922 metais. Steigiamajam Seimui - 90. Sudarytojai S. Kaubrys, A. Vyšniauskas. Vilnius, 2011, p. 139. 
komitetui, be jau minėto V. Putvinskio, priklausè šaulys Petras Ruseckas ${ }^{33}$. Nepaisant to, K. Ralio teigimu, karinė vadovybè ir toliau neigiamai žiūrèjo $\mathfrak{i}$ šaulius ir siekè juos nuginkluoti. To neįvykdžius buvo grasinama neiti savo pareigų ${ }^{34}$.

Gavusi toki pasitikejjimą ir ịpareigojimą, LŠS pradejo plataus masto propagandinę kampaniją, skatindama Lietuvos piliečius prisijungti prie ginkluotųjų pajėgų kovoje prieš lenkus. Šauliai i kovą skatinti šūkiais ir

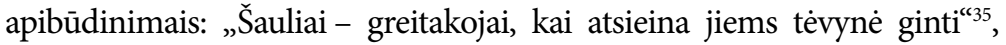
„Vilniečiai - organizuokitès ị šaulių būrị ${ }^{\text {“36 }}$ ir pan. Mobilizuoti šaulius ir visuomenę reikèjo, nes kariuomenè akivaizdžiai negalèjo jèga atsakyti i lenkų išpuolius. Nepaisant Vilniaus krašto praradimo, šauliai aktyviai dalyvaudami kovose dèl Nepriklausomybès sugebejo pagrịsti savo reikalingumą Lietuvos valstybei. Neabejotinai tai lèmè, kad Steigiamojo Seimo nariai prièmè LŠS j̇statymą, be to, pasibaigus kovoms KAM neliko nieko kito, tik pripažinti šaulių indèlị.

\section{Lietuvos šalių sajungos ịstatymo prièmimas: "Čia nèra kokia mobilizacija, nèra prievartos kelias“}

Teisinès bazès reglamentavimas neabejotinai būtų sustiprinęs šaulių padètį, be to, jis būti leidęs organizacijai drąsiau žiūrèti ị ateities veiklą. Aprimus kariniams veiksmams buvo svarstoma, kuriuo keliu turi žengti šauliai: išlaikyti karinę veiklą ar tapti sportine-kultūrine organizacija. Pirmojo kelio šalininkai nuogąstavo, jog leidus LŠS išlaikyti ginklus bus dubliuojama kariuomenès funkcija. $\mathrm{O}$ antrasis kelias neviliojo šaulių vadovybès, nes organizacija būtų praradusi savo išskirtinumą. Būtina pažymėti, kad LŠS ìstatymas Steigiamajam Seimui tikrai nebuvo pirmaeilès reikšmės, tokios

33 Ten pat, p. 138-139.

34192011 05. LŠS CV posėdžio protokolas, Nr. 50. LCVA. F. 561, ap. 2, b. 4296, lap. 72.

35 Naujas pavojus - naujas darbas. Trimitas. 1920, Nr. 7, p. 7.

36 Šaulių būrio reikšmè. Trimitas. 1920, Nr. 10, p. 3. 
pozicijos laikèsi nemažai parlamentarų pasyviai dalyvaudami diskusijose. Bene aiškiausiai tai įvardijo krikščionių demokratų atstovas K. Ambrozaitis, kuris teigè: „Artinantis prie atostogų, man rodos, Seimas turètų pravesti svarbesnius įstatymus, o smulkesnius atideti tolimesniam laikui. " ${ }^{37}$

LŠS įstatymą Steigiamasis Seimas ėmèsi nagrinèti 82-ajame posèdyje $1921 \mathrm{~m}$. balandžio 20 d. Ji svarstymui pateike šaulys, krikščionių demokratų atstovas Jonas Steponavičius. Pranešèjas savo kalboje išskyrè šaulių veiklą ginant Lietuvą nuo lenkų puolimo 1920 m. rudeni, teigdamas, jog šauliai atliko visuomenès telkimo kovai funkciją. Be to, pagrịsdamas tokio įstatymo reikalingumą, parlamentaras kaip pavyzdi pateikė sukarintos organizacijos Suomijoje veiklą ${ }^{38}$. Petras Ruseckas jam antrindamas kaip pavyzdi èmé Šveicarijos pavyzdị: „Aš pabrěšiu Šveicarų apsigynimo būdą. Ten kiekvienas pilietis, sulaukęs tam tikrų metų, dar jaunuoliu būdamas jau ima šautuvą, jau mokinasi šaudyti, jau mokinasi savo kraštą nuo gresiančio pavojaus ginti. “" ${ }^{39}$

Pateiktas įstatymas, turëjęs galutinai teisiškai sutvarkyti Šaulių sajungos padètị valstybèje, buvo svarstomas tris kartus. Posėdžiuose išryškẻjo dvi pagrindinès idėjos dèl LŠS ateities. Pirmosios šalininkai siekẻ pagrịsti organizacijos nepriklausomybę nuo KAM, pasisakė už teisę šauliams turèti ginklus. Apibendrinant galima teigti, jog buvo siekiama turèti pakankamai stiprią sukarintą, ginkluotą organizaciją. Bet svarbiausia - ji turejo būti visiškai savarankiška, savanoriška piliečių organizacija. Šiai pozicijai atstovavo Steigiamojo Seimo nariai (didžioji jų dalis buvo šauliai) J. Steponavičius, P. Ruseckas, J. Pronskus, P. Jočys, V. Bičiūnas, J. Žitinevičius ir kiti. Antroji pozicija savarankiškos LŠS veiklos atžvilgiu buvo kritiška. Bene pagrindinis jos atstovas buvo gen. Jonas Galvydis-Bykauskas. Jam antrino svarstymuose dalyvavęs tuometis krašto apsaugos ministras J. Šimkus, ku-

${ }^{37}$ Steigiamojo Seimo darbai. I sesija. Sąs. 24 (1921), posėdis 115 (1921, liepos 7), p. 10.

${ }^{38}$ Steigiamojo Seimo darbai. I sesija. Sąs. 17 (1921), posèdis 82 (1921, balandžio 20), p. 17-18.

39 Ten pat, p. 19. 
ris neigiamai žiūrèjo ị galimybę LŠS turèti kaip karinę jègą, prioritetą teikdamas sportinès organizacijos idejjai. Faktiškai J. Galvydžio-Bykausko lūpomis buvo išreiškiama visos KAM laikysena. Aktyviausiai ir dažniausiai svarstant LŠS įstatymą pasižymėjo Kazys Škirpa, kuris teikè tiek vertingus esminius pataisymus, tiek ir redakcinio pobūdžio pastabas.

Bene tvirčiausios priešiškos pozicijos laikèsi socialdemokratas $\mathrm{K}$. Venclauskis, kuris teigè, kad šaulių tikslas yra kovoti su manančiais kitaip nei krikščionys demokratai, be to, šaulius jis vadino „buožių baltąja gvardija "40. Savo pozicija išsiskyrė ir krikščionių demokratų atstovė O. Muraškaitė-Račiukaitienė, kuri pasisakẻ prieš sukarinimą ir karinę veiklą. Jos manymu, moterys tokio tipo organizacijoje dalyvauti neturètų ${ }^{41}$. Nepaisant to, LŠS įstatymo svarstymai didžia dalimi buvo šaulių panegirikos renginiai. Parlamentarai nevenge ilgų kalbų, kurių metu buvo ne tik išsamiai apibūdinamos LŠS susikūrimo aplinkybès, bet ir iškeliamas šaulių vaidmuo kovose dèl Lietuvos Nepriklausomybès.

Svarstant įstatymą buvo atsižvelgiama ir ị LŠS CV pastabas, pasiūlymus. Šauliai ịstatymui kèlè tokius reikalavimus: Šaulių sąungai neturi būti primestas visuotinis karinis visuomenès rengimas, turi būti išlaikyta teisè turèti ginklus, tik karinè veikla gali būti kontroliuojama KAM, siekta ịtvirtinti valstybès paramą ir galimybę gauti lèšu iš loterijų, be to, buvo siekiama, jog šaulių veikloje galètų dalyvauti ir moksleiviai ${ }^{42}$. Paradoksas: nors LŠS siekè būti savarankiška organizacija, tačiau kartu bandė užsitikrinti nuolatinị valstybinị finansavimą.

Bene daugiausia ginčų kèlè 4 ịstatymo paragrafas, kuriame buvo kalbama apie LŠS pavaldumą KAM. Šauliai principingai siekè, kad KAM galètų kontroliuoti LŠS veiklą tik tiek, kiek tai yra susiję su karine veikla, o buvo siūloma platesnè priklausomybė. CV narys, Steigiamajame Seime dirbęs

${ }_{40}$ Žilinskas, G. Lietuvos Respublikos Seimai ir Šaulių Sajunga. Šauliškumas, tautiškumas ir Lietuvos Nepriklausomybè. Sudarytojas A. Liekis. Vilnius, 1993, p. 38 .

${ }^{41}$ Lietuvos Steigiamojo Seimo (1920-1922 metu) nariu biografinis žodynas. Sudarytojai A. Ragauskas, M. Tamošaitis. Vilnius, 2006, p. 295.

42192101 23. LŠS CV posèdis, Nr. 54. LCVA. F. 561, ap. 2, b. 4296, lap. 80. 
K. Ralys siūlè ịtvirtinti tokią 4 paragrafo redakciją: „Sąungos darbuotė, kiek tai liečia šaulių karinio auklejimo ir karinio paruošimo, ginklo vartojimo ir karo akcijos, yra Krašto Apsaugos Ministerijos žinioje. Visose kitose srityse vadovaujasi bendrais Valstybès įstatymais. "“3 Tačiau galutinèje ịstatymo redakcijoje buvo ịtvirtinta nuostata, jog „Sajunga priklauso Krašto Apsaugos Ministerijai, kuri teikia jai instruktorius, duoda nurodymus ir kontroliuoja jos veikimą“, be to, šauliams buvo leista turèti visų rūšių ginklus $^{44}$. Tai reiškè, jog šauliams buvo leista likti sukarinta organizacija, galinčia tapti realia karine jèga.

LŠS įstatymas buvo priimtas $1921 \mathrm{~m}$. liepos 7 d. Šaulių laikraštyje „Trimitas" ịstatymo prièmimas buvo pristatytas kaip atmintina diena visiems šauliams, džiaugtasi, kad jis suteikia naujų galimybių ne tik organizacijos nariams, bet ir Lietuvai. Teigta, kad buvo atsižvelgta ị visus LŠS CV pasiūlymus, išskyrus 4 paragrafą ${ }^{45}$. Istatyme buvo nustatytas LŠS tikslas: „Lietuvos Šaulių Sąjungos tikslas - stiprinti ir didinti valstybès gynimo pajègas. " ${ }^{46}$ Formuluotė nesiskyrè nuo tikslo, kuris buvo deklaruojamos LŠS įstatų projekte: „Ginti ir išlaikyti Lietuvos nepriklausomybę visomis jejgomis." ${ }^{47}$ Formuluotejje buvo išlaikyta svarbiausia idejja. Taip pat įstatyme buvo nustatyta, kad LŠS nariais gali tapti ir jaunesni nei 17 metų asmenys, pateikę tèvų sutikimą.

Steigiamajam Seimui prièmus ịstatymą, savo funkcijas turejjo atlikti ir Vyriausybė, parengdama papildomos teisinius aktus. $1921 \mathrm{~m}$. rugpjūčio $23 \mathrm{~d}$. buvo priimti Lietuvos šaulių sąjungos karinès organizacijos dėsniai $^{48}$. Šis teisès aktas reglamentavo LŠS ir KAM administracinius ryšius bei karinę organizacijos veiklą. Nustatyta, kad organizacijos val-

\footnotetext{
192107 06. LŠS CV posėdžio protokolas, Nr. 63. LCVA. F. 561. ap. 2, b. 4296, lap. 112.

${ }^{44}$ Lietuvos šaulių sajungos įstatymas. Vyriausybès žinios. 1921, Nr. 70, p. 5.

45 Atmintina diena šauliams. Trimitas. 1921, Nr. 28. p. 3.

${ }^{46}$ Lietuvos šaulių sajungos įstatymas. Vyriausybès žinios. 1921, Nr. 70, p. 5.

47 1920. LŠS įstatų projektas. LCVA. F. 561, ap. 2, b. 46, lap. 12.

${ }^{48}$ Lietuvos šaulių sajungos karinès organizacijos dèsniai. Vyriausybès žinios. 1921, Nr. 71, p. 5-6.
} 
dymą KAM kontroliuos per paskirtą Vyriausiąji šaulių sąjungos karo instruktorių. Be to, dèsniuose buvo reglamentuotas šaulių ginklų laikymas, jų registracija ir pan. ${ }^{49}$ Faktiškai priimtuose dèsniuose atsispindejo pagrindiniai ginčytini klausimai, iškilę svarstant LŠS įstatymą. Pagal ši Vyriausybès priimtą teisès aktą KAM išlaikė pakankamai didelę ittaką organizacijos karinei veiklai. Pirmuoju Vyriausiuoju šaulių sąungos instruktoriumi buvo paskirtas tuomet dar majoras Stasys Zaskevičius, kuris pradèdamas eiti savo pareigas teigè: „Mes Jums duosime karini prityrimą, karinę drausmę ir karinị mokslą, o Jūs pasidalysit su mumis pilietine sąmone ir pasiryžimu kovoti iki galui. Taip, ranka ị ranką eidami nežlugsim, nes nèra tos spèkos, kuri mus sunaikintų. ${ }^{\text {"50 }}$ Nepaisant pakilaus tono, mjr. S. Zaskevičiui teko susidurti su dideliu priešiškumu. LŠS vadovybė jau buvo spejjusi įdiegti nepasitikèjimo ir siekio prieštarauti KAM nustatytai tvarkai daigus.

\section{Išvados}

1. Atliekant tyrimą nustatyta, kad LŠS nariai tarp visų Steigiamojo Seimo narių sudare 17,3 proc. (skaičiuojant iš visų 150 Steigiamojo Seimo narių 1920-1922 metais, 26 priklausė LŠS). Didžioji dalis Steigiamojo Seimo narių šaulių priklausẻ krikščionių demokratų ir valstiečių liaudininkų blokams, taigi turejjo galimybę savo mintis reikšti ir įstatymų projektus svarstyti didžiausiose Steigiamojo Seimo frakcijose. Tai lèmè ir sẻkmingą LŠS ịstatymo svarstymo ir prièmimo procedūrą Steigiamajame Seime.

2. LŠS teisę ị atskirą, jos veiklą reglamentuojantị ịstatymą užsitarnavo aktyviai dalyvaudama kovose dèl Lietuvos Nepriklausomybès. Be to, nemažą ittaką šiame procese vaidino šauliai Steigiamojo Seimo nariai, tarp kurių išsiskyrè valstiečių liaudininkų blokui priklausęs K. Ralys. Steigiamasis Seimas pasitikẻjimą sukarinta organizacija išreiškè ne tik skatinda-

49 Ten pat, p. 5-6.

5019211007 . Vyriausiojo Šaulių sąungos karo instruktoriaus įsakymas Nr. 3. LCVA. F. 561, ap. 2, b. 98. lap. 2. 
mas KAM pateikti LŠS ịstatymą, bet ir įtraukdamas šaulių atstovą i prie parlamento sudaromas komisijas.

3. LŠS pagal teisini pobūdị buvo unikali sukarinta organizacija, nes veikè pagal parlamento priimtą ịstatymą. Steigiamojo Seimo 1921 m. priimtas pirmasis LŠS įstatymas išsaugojo sukarintos organizacijos veiklos specifiką bei užtikrino valstybès paramą ir kartu kontrolę per KAM. Būtina pažymèti, kad Šaulių sajunga netapo sportine-kultūrine organizacija, kaip siekė karinei vadovybei atstovavę to meto politikai (J. Galvydis-Bykauskas). Didelę ịtaką sèkmingam LŠS įstatymo prièmimui turèjo ne tik šaulių dalyvavimas kovose dèl Nepriklausomybès, bet ir kryptinga šaulių Steigiamojo Seimo narių veikla.

\section{LITHUANIAN RIFLEMEN'S UNION ASPECT OF THE HISTORY OF PARLIAMENTARIANISM IN LITHUANIA: SEIMAS CASE}

\section{Mindaugas Nefas}

\section{Summary}

Keywords: Lithuanian Riflemen's union; Constituent Assembly (Seimas); law; Ministry of National Defence; parliamentarian; "šauliškumas" (ideology of Riflemen).

In the article there is analysed the subject of Lithuanian Riflemen's union in the work of Constituent Assembly (Seimas). The movement of LRU members who worked in Seimas in 1920 - 1922 is analysed according to the biographical dictionary of Seimas members as well as LRU Central Board meetings, the protocols of Seimas and historiographical positions, in order to establish a legislative framework for LRU. Paramilitary organization - Lithuanian Riflemen Union started its activities during the fights for Lithuanian independence and therefore earned the trust from Lithuanian government. In accordance with the principles of activities, this organizations was not without analogies, but its activity was regulated by laws and that is why LRU was an exclusive organization. Riflemen support at the political level was not the same. Seimas placed confidence in the organization (for example in 1921 there was adopted LRU law), while the Ministry of Defence comprehen- 
sively wanted to control the Riflemen and remove the self-management capabilities. As a proof that Lithuanian government appreciates the activity of organization's members, in 1921 there was adopted the first LRU law and in addition established only partial dependence from the Ministry of Defence.

The aim of the work is to determine the impact of Seimas members, who belonged to Lithuanian Riflemen's Union, for the creation of the legislative base of the LRU. The goal of the work will be achieved by estimating the number of Riflemen who worked in Seimas and by analysing their activities in the Parliament and their impact to adopt the organization's activities legislation.

The investigation showed that the LRU members in Seimas reached 17.3 percent (from 150 MPs 26 of them belonged to LRU in 1920 - 1922). Most of the Riflemen from Seimas were the members of the Christian Democrats and Lithuanian Popular Peasants' units, therefore they had the opportunity to contribute to consideration of laws in the largest Seimas factions. This resulted in a successful LRU law consideration and adoption procedure in Seimas.
LRU has earned the right to a separate law by participating actively in the fights for Lithuanian independence. Furthermore, a significant influence in this process played Riflemen - members of Seimas, among them stood out K. Ralys who belonged to Lithuanian Popular Peasants' unit. Seimas expressed their confidence in the paramilitary organization not only by encouraging Ministry of Defense to provide LRU law, but also by including the representative of Refilemen to the commissions of the parliament.

LRU by its legal format was a unique paramilitary organization because it acted in accordance with the law adopted by parliament. The first LRU law adopted by Seimas in 1921 retained a paramilitary organization specifics and assured state support and control over the Ministry of Defence. It should be noted that the Riflemen Union did not become sports - cultural organization, although the politicians representing the military leadership pursued to do so (J. Galvydis-Bykauskas). A significant impact on the success of LRU law was not only the participation in the battles for the independence but also targeted Riflemen - Seimas members' activities.

Iteikta $2015 \mathrm{~m}$. liepos $10 \mathrm{~d}$. 